SHS Web of Conferences 2, 00006 (2012)

DOI: $10.1051 /$ shsconf $/ 20120200006$

(C) Owned by the authors, published by EDP Sciences, 2012

\title{
Higher education status in public value orientation
}

\author{
I. Bolgzda and E. Olehnovica
}

\author{
Daugavpils University, Latvia
}

\begin{abstract}
In the article the interrelationships between the types of dominating values in the society and corresponding consequences for higher education aims and objectives. In the context of the mentioned interrelationships, there are given the examples of studies offered by the USA and Daugavpils University, as well as the access to value structuring and typology found in scientific literature. The surveyed study results render the public evaluation on the instrumental and terminal values of the higher education. Authors pay a special attention to systemic view or four quadrant matrix use in the analysis of value formation process. Semantic analysis of the concept "knowledge" and hermeneutic interpretation depict the direct connection of the education with individual and collective values. By determining the values dominating in the public, one can predict its expectations in the field of education and adapt it to the necessary changes.
\end{abstract}

Key words: higher education, education status, public value orientation

Value system is an essential public and individual's aspect of existence, the reflection of its needs, ideals and aims. Education is that field of public life, in which the interrelationship between the beforementioned components is especially emphasized. The aim of the article is to mark the public value orientations and higher education interrelationships, which can point to the present education aims and objectives.

The current society characteristics are typical for several signs of various content - postmoderrnist society, knowledgeable society, information and cosumers' society. Each of these signs has its philosophy, as well as corresponding consequences in the education. Multi-dimensional characteristics of the society is the reason for mutual controversies, for instance, if the knowledgeable society requires creativity and innovation, then consumer society's greatest problem is unwillingness to create, but the only wish is to gain. Education itself has become an individual's consumer product. Consumer-oriented society expects from the education professional executers and functioners (Николаева, Шелкунов, 2009). With the consumer's philosophy being dominant, the education is focussed on short-term gains, competition, control/responsibility dominance, - these are signs which are unstable by nature.

The field of value orientation effect is very broad, among it also of education status in the society. In the research on values dominating in the society, which was carried out in the USA by a sociologist P.H.Ray and psychologist Anderson within the period from 1965-2000 (Ray, Anderson, 2000), who have concluded that in the society, as a carrier of different values, there simultaneously exist three subcultures: traditionalists $-24 \%$ USA population adhere to traditional, constant values:

- Modernists $-47 \%$ population whose value score contains a lot of material, pragmatic and rational things. Their opinion is that if something cannot be expressed in measurable categories, then it simply does not exist. Highly evaluated is the individual's freedom, career and financial welfare. Modernists' world outlook at present is dominating, therefore it makes an impression that it is the only correct one.

- Cultural creatives - this term was introduced by the study authors, because the carriers of this subculture are the indicators of culture and value changes, which stress the authenticity, holism, alternative approach towards long-term processes and thinking. This part of subculture has a

This is an Open Access article distributed under the terms of the Creative Commons Attribution License 2.0, which permits unrestricted use, distribution, and reproduction in any medium, provided the original work is properly cited. 


\section{SHS Web of Conferences}

tendency to increase from $3 \%$ in 1965 to $29 \%$ in 2000. Similar processes are seen in Europe as well (according to the study data acquired by EU secretariat in 1997 in 15 European countries).

- Undoubtedly, these different value orientations are implied in the education content and aims. Just the subculture group of cultural indicators is now moving the processes of education changes, because in the 21 st century the higher education is an essential instrument in attaining strategic aims of the society.

- Therefore an issue on higher education status in the context of value orientation society is offered for reflection: whether the higher education is the aim or means? Whether education is a service or public benefit? Answers cannot be found without a deeper value analysis.

\section{Value typology}

Values are active management principles and, considering the fact, that the education philosophy paradigm changes from teaching (principle of utility) to learning (principle of motivation), it is important to understand the interior character of values and dynamics. In unstable socially economic conditions, market forces and pragmatic interests take the upper hand over the statement of knowledge value. It does not enhance the components of the academic education - learning of research skills, which, at present in Latvia's situation, is extremely essential.

Thus, the value of education is reduced to the level of instrumental, economic benefit (Robeyn, 2006; 73), but, education is not only an upkeep of specific competence and qualification, but rather the process to develop talent, emotional, social intelligence and personality" (Latvijas ilgtspējīgas attīstības stratēgija līdz 2030. gadam, 17. lpp.).

Two value types are seen to develop, whose theoretical foundation is found in axiologist's M.Rokic division of values:

- instrumental values: values - means, are influenced by conditions and possibilities, therefore there is a varied internal hierarchy;

- terminal values: values - aims, view in perspective, skills to set targets in one's life and place in life. It has to be mentioned, that the value types mentioned do not exclude each other, therefore they should be viewed from complimentarity principle, or the view of mutual compliment. The understanding of values has changed historically, alongside with the develpment of the society. Today a separate branch of science - axiology has developed from old Greek philosophy (greek axios - valuable, logos - study), whose founder is M.Scheler. He was of the opinion that values are specific facts, they are objective and secular, their inner hierachy does not depend on the environmental forms and carriers of values. Nowadays the concept persists, that values are the social characteristics of objects of the outside world.

In research the values are analyzed in various ways: as a philosophical category, as logic or mental law, and as the before mentioned synthesis. G.E. Moor stresses the cognitive approach and offers a formula: $\mathrm{x}=$ value or values are those which imply knowledge of values. The founder of formal axiology R. Hartmann, on the other hand, formulates the value language as ethics with three types of analysis: analysis of moral sphere which is indefinite and changeable, arbitrary interpretation of empirical analysis and precise empirical research, by applying certain formulas.

\section{Hermeneutics of notion knowledge}

Formulations of values and typology along history circles have changed depending on the conditions, socially political interests, various theories of some thinkers. The first philosophical perceptions were created by Aristotle. At that time the Greek philosophers in their explanations used a rich language, concentrating on 58 sense of the word.

Use of heremeneutics in the analysis of education notions allows to discern intrinsic interrelationships and better fix the value content. As we know, the total knowledge acquired (at any 
Int. Conf. SOCIETY. HEALTH. WELFARE; Congr. of Rehabilitation Doctors of Latvia

Table 1. Made by the authors, using K. Wilber's matrix.

\begin{tabular}{|l|l|}
\hline "I" & "THAT" \\
Motivation & $\begin{array}{l}\text { Individual activities, creativity, life strategy, } \\
\text { knowledge management, effectiveness, } \\
\text { knowledge utility or applicability }\end{array}$ \\
\hline "WE" & "BELONGING TO THAT" \\
$\begin{array}{l}\text { Cultural traditions, universal values, } \\
\text { collective heritage, national identity, } \\
\text { knowledgeable society, human capital, } \\
\text { expectations }\end{array}$ & $\begin{array}{l}\text { education, public strategy, sustainability, } \\
\text { social benefit, ecological thinking, } \\
\text { noosphere }\end{array}$ \\
\hline
\end{tabular}

knowledge level) can be very different as to its quality. It can be seen when explaining the semantic idea of the term knowledge in old Greek:

- epignesis (background sensual perception, factological knowledge, distracted from the personality of the knowledge carrier);

- phronesis (practical wisdom, skills to adapt and sort the facts, critical mind, intellect, action based on normative acts);

- sophia (level of mental wisdom, which is implemented in posture, mind, creativity, holistic vision, perception of the essence and sense of life).

The before mentioned nuances point to the essential distinctions at various levels of the quality of knowledge. We can conclude that the knowledge itself does not guarantee the wisdom. The acquired instrumental knowledge should be intervened with motivation, conviction and understanding of perception. It has to be taken into account, that this semantic gradation is mutually very much connected and supplementing each other, but the decisive point here is not to lose the dynamics of personality growth.

If we implicate M.Rotic' value typology into this method, then it fits phronesis and sophia level. For the effective functioning of the present day society, we need the knowledge with the value added, the knowledge which is defined by the concept - sophia.

\section{Analysis of interrelationship of education and public value orientation in the aspect of holistics}

The insight into the history of value typology and research approaches depicts the interaction of philosophic, psychological, economic, sociologic and culturally social phenomena. To acquire a systemic view on the public attitude to the education as a value, we can use the method offered by K.Wilber, whose integral model or four quadrant matrix OQAL covers several layers of reality and at present is widely used in very different research fields, starting from politics and ending with personality analysis. The key words written into the quadrants allow us comprehensively analyze the education value both horizontally, or at real practice level, and vertically, or at the level of ideals.

Any of four matrix quadrants is the interrelationship both in the horizontal, and vertical direction, consequently depicting the individual and collective value interrelationship, as well as in the educational roots in public value system.

\section{Value of higher education in Latvia's society: Studies done}

What is the role of higher education for the society in Latvia? In 2006 the Latvian Strategic commission carried out a study, "Dzīves kvalitātes indekss" (Index of Life Quality). By questioning the inhabitants of Latvia, the role of higher education was identified as being valued higher in comparison to other levels of education. However, such a conclusion still does not give the answer to the question, whether 


\section{SHS Web of Conferences}

education is the aim or the means in the society's value orientation, or, perhaps, both together? Each of these positions has its consequences in the value system.

In order to determine the education as economic and sustainable effect of the value, both at the society level, and individual level, there is still needed an in-depth research and analysis. A.Šnitnikova and S.Vanaga made a study in 2002, "Daugavpils Universitāte kā Latgales reǵgiona attīstības centrs: augstākās izglītības un darba tirgus dialoga veicināšana" (Daugavpils University as Latgale regional centre: enhancement of the dialogue on higher education and labour market). By using cost-benefit analysis in their study, the answer was acquired to the question, whether the higher education in Latvia is economically profitable? On the contrary, in a different study of Daugavpils University Social study institute, "Jaunatne cel̦ā no izglìtỉbas uz darba tirgu" (Youth on their way from education to labour market) the analysis of young people's choice of strategy of life was done, depending on the education level.

The data of both studies give the idea of the society's evaluation of instrumental and terminal value of higher education. By determining and analyzing the value of higher education from the society's perception, one can predict the further developmental tendencies, fitting to the necessary changes.

Up to the present, in Latvia, the higher education status, in the context of future public philosophy, is marked by several developmental strategies, but to a lesser extent by research. Determining and analyzing the education values in the context of society, one can prognose the developmental tendencies, adapting them to necessary changes.

\section{Conclusions}

1. Higher education status in public value orientation is estimated bilaterally: both as an aim (instrument) in attaining economic achievements, and as means for creating the opportunities of new life and personality. Modern education must give a corresponding result for understanding future public values.

2. In unstable socially economic conditions, market forces and pragmatic interests prevail over value affirmation. It does not succeed in acquisition of the component of academic education - research skills, which is very significant in present Latvia's situation. Thus, education value becomes reduced to the instrumental, economical benefit, but education is not only the maintenance of specific competences and qualification, but the process of development of emotional, social intelligence and personality development.

3. Higher education in the view of Latvian society is perceived as recognizable value, however, in the context of public value orientation is not studied holistically, trying to to find out, what values define the education content and objectives. The answer to the before mentioned will determine, to what extent Latvian society can be defined as a knowledgeable society, thus making the basis for sustained development.

4. The question forwarded for discussions: whether public value orientation is an aim or the means? remains open.

\section{References}

[1] Hartman, R. (1961) The Logic of Value. The Review of Metaphysics, Vol. 14, 3, p. 89-432.

[2] Latvijas Stratēǵiskās analīzes komisijas pētījums (2006) Dž̄ves kvalitātes indekss. http://www.latvija2030.1v/upload/lias_1redakcija_pilnv_final.pdf

[3] Ostrovska, I., Boroņenko, V. (2004) Jaunatne cȩ̣ā no izglītības uz darba tirgu. http://opensigle.inist.fr/handle/10068/327966

[4] Ray, P.H., Anderson, Sh.R. (2000) The Cultural Creatives. New York: Harmony Book.

[5] Robeyn, I. Three models of education: Rights, Capabilities and Human capital. http://tre.sagepub.com/content/4/1/69.abstract 
Int. Conf. SOCIETY. HEALTH. WELFARE; Congr. of Rehabilitation Doctors of Latvia

[6] Vanaga, S., Šņitņikovs, A. Daugavpils Universitāte kā Latgales reǵiona attīstības centrs: augstākās izglītības un darba tirgus dialoga veicināšana. http://www.politika.lv/index.php?id=6116

[7] Vilbers, K. (2010) Visaptverošā teorija. Rīga: Jumava,70 lpp.

[8] Николаева Е.М., Шелкунов, М.Д. (2009) Образование в обществе потребления. Философия образования, 1, с. 11-18. http://dlib.eastview.com/ searchresults/article.jsp?art=312\&id=21882127 